\title{
PENGARUH KOMPENSASI TERHADAP MOTIVASI KERJA, KEPUASAN KERJA, DAN KINERJA KARYAWAN (Studi pada Karyawan Tetap PT. Otsuka Indonesia di Lawang, Malang)
}

\author{
Yanda Bara Kusuma, Bambang, Swasto S., Mochammad Al Musadieq \\ Fakultas Ilmu Administrasi Universitas Brawijaya Malang \\ Email: yandabara@yahoo.com
}

\begin{abstract}
The background of this research is the compensation policy of a company's performance helped determine the direction of its employees to support the company's goals. Compensation is one of the important factors to be able to attract potential employees. Work motivation is also another factor that must be considered in addition to compensation for employees of the company to realize the goals of the organization, the following job satisfaction. Those three things are important factors in the company to support employee performance. This study aimed to examine the effect of compensation on work motivation, job satisfaction, and performance of employees on permanent employees of PT. Otsuka Indonesia in Lawang, Malang. Formulated several hypotheses of the study are (1) Is compensation a significant effect on work motivation? (2) Is compensation a significant effect on job satisfaction? (3) Is compensation a significant effect on the performance of the employee? (4) Is the work motivation have a significant effect on job satisfaction? (5) Is a significant effect on employee motivation employee performance ?, (6) Is job satisfaction significantly influence employee performance?. This research is explanatory research with quantitative approach. The technique of collecting data from questionnaires and interviews. Research methods to process the data using path analysis. Based on the results of the study found a significant effect of compensation on employee motivation PT. Otsuka Indonesia, there is a significant effect of compensation on employee job satisfaction of PT. Otsuka Indonesia, there is a significant influence on the performance of the compensation of employees of PT. Otsuka Indonesia, there is a significant effect of work motivation on employee job satisfaction of PT. Otsuka Indonesia, there is a significant influence on the performance of the work motivation of employees of PT. Otsuka Indonesia, and found no significant effect of job satisfaction on the performance of employees of PT. Otsuka Indonesia. Employees of PT. Otsuka Indonesia are already satisfied with the salary he got in a long time felt it would be a regular thing. So prone to reduced performance, because by working casual or work hard to remain earned his salary by the same amount. Employees of PT. Otsuka Indonesia also feel responsibility for the work carried out so far have not been entirely in accordance with his ability means that the principle of "the right man on the right place" has not been felt by the employees of PT. Otsuka Indonesia. Interesting work and the work has not felt like a hobby for PT. Otsuka Indonesia as yet incompatibility refers to the responsibility of the employee's ability to be felt.
\end{abstract}

Keywords: Compensation, Work Motivation, Job Satisfaction, Employee Performance 


\begin{abstract}
ABSTRAK
Latar belakang penelitian ini adalah kebijakan kompensasi sebuah perusahaan turut menentukan arah kinerja karyawannya hingga menunjang tujuan perusahaan. Kompensasi adalah salah satu faktor penting untuk dapat menarik calon karyawan. Motivasi kerja juga faktor lain yang harus diperhatikan perusahaan selain kompensasi bagi karyawan demi terwujudnya tujuan dalam organisasi, berikut kepuasan kerja. Ketiga hal tersebut adalah faktor-faktor penting dalam perusahaan guna menunjang kinerja karyawan. Penelitian ini bertujuan untuk menguji pengaruh kompensasi terhadap motivasi kerja, kepuasan kerja, dan kinerja karyawan pada karyawan tetap PT. Otsuka Indonesia di Lawang, Malang. Dirumuskan beberapa hipotesis penelitian yaitu (1) Apakah kompensasi berpengaruh signifikan terhadap motivasi kerja? (2) Apakah kompensasi berpengaruh signifikan terhadap kepuasan kerja?(3) Apakah kompensasi berpengaruh signifikan terhadap kinerja karyawan? (4) Apakah motivasi kerja berpengaruh signifikan terhadap kepuasan kerja? (5)Apakah motivasi kerja berpengaruh signifikan terhadap kinerja karyawan?, (6)Apakah kepuasan kerja berpengaruh signifikan terhadap kinerja karyawan?. Jenis penelitian ini adalah penelitian eksplanatoris dengan pendekatan kuantitatif. Teknik pengumpulan data dari kuesioner dan wawancara. Metode penelitian untuk mengolah data menggunakan analisis jalur (path analysis). Berdasarkan hasil penelitian ditemukan pengaruh yang signifikan dari kompensasi terhadap motivasi kerja karyawan PT. Otsuka Indonesia, terdapat pengaruh yang signifikan dari kompensasi terhadap kepuasan kerja karyawan PT. Otsuka Indonesia, terdapat pengaruh yang signifikan dari kompensasi terhadap kinerja karyawan PT. Otsuka Indonesia, terdapat pengaruh yang signifikan dari motivasi kerja terhadap kepuasan kerja karyawan PT. Otsuka Indonesia, terdapat pengaruh yang signifikan dari motivasi kerja terhadap kinerja karyawan PT. Otsuka Indonesia, dan ditemukan pengaruh yang tidak signifikan dari kepuasan kerja terhadap kinerja karyawan PT. Otsuka Indonesia. Karyawan PT. Otsuka Indonesia yang sudah puas dengan gaji yang didapatkannya dalam waktu yang lama hal tersebut akan dirasa menjadi hal yang biasa. Sehingga rawan akan menurunnya kinerja, karena dengan bekerja santai ataupun bekerja keras gajinya akan tetap didapatkan dengan jumlah yang sama. Karyawan PT. Otsuka Indonesia juga merasa tanggung jawab pekerjaan yang dilakukan selama ini belum sepenuhnya sesuai dengan kemampuannya artinya prinsip "the right man on the right place" belum dirasakan oleh karyawan PT. Otsuka Indonesia. Pekerjaan yang menarik dan pekerjaan bagaikan hobi juga belum dirasakan karyawan PT. Otsuka Indonesia karena mengacu belum sesuainya kemampuan karyawan dengan tanggung jawab yang harus dirasakannya.
\end{abstract}

\title{
Kata Kunci : Kompensasi, Motivasi Kerja, Kepuasan Kerja, Kinerja Karyawan
}




\section{PENDAHULUAN}

Sumber daya manusia adalah salah satu sumber daya yang ada di dalam perusahaan, selain sumber daya yang lain seperti modal, material, dan mesin. Sumber daya manusia dalam perusahaan bersifat dinamis karena sering berubah fungsi dan tujuannya bergantung kemauan manusia itu sendiri. Dalam menjalankan aktivitas usahanya, sebuah perusahaan bertumpu pada kualitas kinerja yang ditunjukkan oleh para karyawannya. Semakin baik kinerja karyawan maka akan berbanding lurus dengan hasil dan tujuan yang telah ditetapkan oleh perusahaan. Oleh sebab itu, perusahaan harus lebih memberikan perhatian kepada para karyawannya. Perhatian tersebut adalah yang bersifat bisa memenuhi kebutuhan karyawannya, karena pada dasarnya keinginan untuk memenuhi kebutuhan adalah salah satu faktor yang mendorong karyawan untuk melakukan pekerjaan.

Menurut Hasibuan (2002:135) kompensasi atau balas jasa umumnya bertujuan untuk kepentingan perusahaan dan karyawan. Kepentingan perusahaan dengan pemberian kompensasi yaitu memperoleh imbalan berupa prestasi kerja yang lebih besar dari karyawan. Kepentingan karyawan atas kompensasi yang diterima, yaitu dapat memenuhi kebutuhan dan keinginannya dan menjadi keamanan ekonomi rumah tangganya. Kompensasi adalah salah satu faktor penting untuk dapat menarik calon karyawan, juga dapat sebagai penyemangat dan mempertahankan karyawan lama untuk meningkatkan kinerjanya terhadap perusahaan. Kompensasi terdiri dari kompensasi finansial dan kompensasi non finansial. Termasuk dalam kompensasi finansial antara lain bayaran pokok (gaji, upah), bayaran prestasi (bonus, premi), insentif, dan tunjangan-tunjangan, serta bayaran di luar jam kerja (upah lembur, cuti tahunan, cuti lainnya), dan program proteksi (asuransi tenaga kerja). Sedangkan termasuk kompensasi non finansial berupa pekerjaan dengan tanggung jawab yang besar dan berpengaruh, sarana kantor yang baik,dan lain-lain.
Motivasi adalah hal yang mendasar selain kompensasi bagi karyawan demi terwujudnya tujuan dalam organisasi. Perusahaan harus mampu membangkitkan motivasi yang ada dalam diri karyawan tersebut. Faktor motivasi kerja sangat berhubungan dengan perilaku yang diarahkan pada tujuan. Simamora (2006:487) mengemukakan bahwa para karyawan termotivasi untuk mendapatkan kompensasi yang berimbang terhadap kinerja mereka dan selanjutnya kepuasan kompensasi yang mereka terima juga akan mempengaruhi motivasi mereka untuk bekerja secara produktif dan efisien. Penjelasan di atas didukung oleh hasil penelitian dari Ulfa (2013) yang menyebutkan bahwa ada pengaruh yang kuat antara kompensasi finansial terhadap motivasi karyawan dan kompensasi non finansial terhadap motivasi karyawan pada karyawan AUTO

2000 di Kota Malang.

Motivasi kerja yang positif dirasakan oleh karyawan erat kaitannya dengan kepuasan kerja yang juga akan dirasakan oleh para karyawan. Penelitian oleh Stringer et al. (2011) menyebutkan bahwa motivasi intrinsik dan ekstrinsik memberikan dampak yang positif terhadap kepuasan kerja. Kepuasan kerja adalah keadaan di mana karyawan merasa nyaman dengan apa yang telah diperolehnya. Kepuasan kerja ini bersifat relatif bagi setiap karyawan. Artinya tidak ada batasan tertentu untuk mengukur tingkat kepuasan kerja. Smith et al. dalam Gibson (2006), menyatakan bahwa faktor- faktor yang mempengaruhi kepuasan atau ketidakpuasan kerja yaitu : Perasaan senang atau tidak senang terhadap pembayaran, perasaan senang atau tidak senang terhadap pekerjaan, perasaan senang atau tidak senang terhadap kesempatan memperoleh promosi, perasaan senang atau tidak senang terhadap penyelia, perasaan senang atau tidak senang terhadap rekan kerja.

Kinerja karyawan adalah hasil bekerja oleh karyawan untuk menghasilkan barang ataupun jasa. Baik buruknya kinerja karyawan bisa dipengaruhi banyak faktor, seperti gaji dan upah pada umumnya, motivasi dalam bekerja serta kepuasan dalam bekerja. 
Mathis dan Jackson (2006) menjelaskan bahwa kinerja pada dasarnya adalah apa yang dilakukan atau tidak dilakukan karyawan. Kinerja karyawan adalah yang mempengaruhi seberapa banyak mereka memberi kontribusi kepada organisasi yang antara lain termasuk kuantitas output, kualitas output, jangka waktu output, kehadiran di tempat kerja, sikap kooperatif. Sering terjadi kinerja karyawan menurun dikarenakan kemungkinan adanya ketidaknyamanan dalam bekerja, gaji atau upah minim, motivasi dan juga ketidakpuasan dalam bekerja.

Perusahaan yang menjadi tempat penelitian adalah PT. Otsuka Indonesia yang berlokasi di Lawang, Kabupaten Malang. Alasan akan dilakukan penelitian ini di PT. Otsuka Indonesia oleh peneliti adalah karena PT. Otsuka Indonesia adalah salah satu pelopor perusahaan yang memproduksi produk farmasi di Indonesia. Artinya sebagai salah satu pelopor perusahaan di bidang produk farmasi, kebijakan awal terkait kompensasi hingga menunjang kinerja karyawannya dalam sebuah perusahaan di bidang farmasi turut menentukan arah dan tujuan perusahaan ke depannya. Buktinya hingga saat inipun PT. Otsuka Indonesia tetap menjadi yang terdepan sebagai produsen produk-produk farmasi di tengah persaingan yang ada dengan produsen lain yang serupa. Berdasarkan latar belakang di atas, maka rumusan masalah dalam penelitian ini adalah :

1. Apakah kompensasi berpengaruh signifikan terhadap motivasi kerja?

2. Apakah kompensasi berpengaruh signifikan terhadap kepuasan kerja?

3. Apakah kompensasi berpengaruh signifikan terhadap kinerja karyawan?

4. Apakah motivasi kerja berpengaruh signifikan terhadap kepuasan kerja?

5. Apakah motivasi kerja berpengaruh signifikan terhadap kinerja karyawan?

6. Apakah kepuasan kerja berpengaruh signifikan terhadap kinerja karyawan?

\section{LATAR BELAKANG TEORI DAN HIPOTESIS}

\section{Kompensasi dan Motivasi Kerja}

Kompensasi adalah hal yang menjadi daya tarik bagi seorang karyawan. Karyawan yang puas dengan kompensasi yang diterima dari perusahaan memiliki kecenderungan untuk bekerja optimal demi kemajuan perusahaan. Mondy (2008:4) mengemukakan kompensasi adalah total seluruh imbalan yang diterima para karyawan sebagai pengganti jasa yang telah mereka berikan. Kompensasi dibagi menjadi kompensasi finansial dan kompensasi non finansial. Rivai (2009:758) menerangkan bahwa kompensasi finansial terdiri dari gaji,upah, dan insentif. Mondy (2008:5) menerangkan bahwa kompensasi non finansial meliputi kepuasan yang diterima seseorang dari pekerjaan itu sendiri atau dari lingkungan psikologis dan/ atau fisik tempat orang tersebut bekerja. Kajian konseptual pengaruh kompensasi terhadap motivasi kerja seperti yang diuraikan Notoatmodjo (2003:153) yang menyatakan bahwa besar kecilnya kompensasi dapat mempengaruhi prestasi kerja, motivasi dan kepuasan kerja karyawan.

Indikator dari variabel kompensasi, yaitu kompensasi finansial dan kompensasi non finansial didukung oleh hasil penelitian Ulfa (2013) yang membuktikan bahwa kompensasi finansial dan kompensasi non finansial berpengaruh signifikan positif terhadap motivasi kerja. Pengaruh kompensasi finansial terhadap motivasi kerja tersebut signifikan positif, sehingga semakin dilaksanakan dengan baik kompensasi finansial yang diberikan kepada karyawan akan dapat memotivasi karyawan untuk bekerja. Sedangkan kompensasi non finansial terhadap motivasi kerja tersebut juga bersifat signifikan positif, sehingga dapat dikatakan bahwa kompensasi non finansial yang diberikan juga dapat memotivasi karyawan untuk lebih bekerja dengan giat dan meningkatkan kualitas dari pekerjaannya. Berdasarkan tinjauan teori dan hasil penelitian sebelumnya dirumuskan hipotesis penelitian sebagai berikut:

Hipotesis 1 : Kompensasi berpengaruh signifikan terhadap Motivasi Kerja. 


\section{Kompensasi dan Kepuasan Kerja}

Menurut Wibowo

(2011:348)

kompensasi merupakan kontra prestasi terhadap penggunaan tenaga atau jasa yang telah diberikan oleh tenaga kerja. Berkaitan dengan pengaruh kompensasi terhadap kepuasan kerja, Simamora (2006:448) menyebutkan kepuasan (satisfaction) merupakan istilah evaluatif yang menggambarkan suatu sikap suka atau tidak suka. Kepuasan bayaran (pay satisfaction), oleh karenanya, mengacu pada sikap suka dan tidak suka terhadap sistem kompensasi organisasi.

Hasil penelitian Supatmi (2013) membuktikan bahwa kompensasi berpengaruh signifikan terhadap kepuasan kerja karyawan. Artinya kompensasi berpengaruh secara

bermakna terhadap kepuasan kerja karyawan. Hubungan dua variabel ini juga positif dimana semakin tinggi kompensasi yang diterima karyawan maka akan semakin tinggi pula kepuasan kerja yang dirasakan karyawan. Berdasarkan tinjauan teori dan hasil penelitian sebelumnya dirumuskan hipotesis penelitian sebagai berikut:

Hipotesis 2 : Kompensasi berpengaruh signifikan terhadap Kepuasan Kerja.

\section{Kompensasi dan Kinerja Karyawan}

Mathis dan Jackson (2009:419) mendefinisikan kompensasi sebagai imbalan yang diberikan kepada karyawan oleh perusahaan atas pekerjaan dan tanggung jawab yang diberikannya kepada perusahaan. Mangkuprawira (2009:67) berpendapat bahwa kinerja adalah hasil kerja secara kualitas dan kuantitas yang dicapai oleh seorang pegawai dalam melaksanakan tugasnya sesuai dengan tanggung jawab yang diberikan kepadanya. Oleh karena hal tersebut di atas maka kompensasi harus dikelola dengan baik, karena kompensasi membantu perusahaan untuk mencapai tujuan dan memperoleh, memelihara, dan menjaga karyawan dengan baik.

Pendapat di atas didukung dengan hasil penelitian Prasetya dan Kato (2011) yang membuktikan bahwa terdapat pengaruh yang signifikan dari kompensasi baik finansial dan non finansial terhadap kinerja karyawan. Artinya bahwa dengan peningkatan kompensasi yang diberikan oleh perusahaan, maka akan meningkatkan kinerja karyawan. Besarnya kompensasi ini mencerminkan status, pengakuan dan tingkat pemenuhan kebutuhan yang dinikmati karyawan bersama keluarganya. Berdasarkan tinjauan teori dan hasil penelitian sebelumnya dirumuskan hipotesis penelitian sebagai berikut: Hipotesis 3 : Kompensasi berpengaruh signifikan terhadap Kinerja Karyawan.

\section{Motivasi Kerja dan Kepuasan Kerja}

Wibowo (2011:379) berpendapat bahwa motivasi merupakan dorongan terhadap serangkaian proses perilaku manusia pada pencapaian tujuan. Teori motivasi yang digunakan sebagai acuan

yaitu teori ERG (Existence, Relatedness, Growth) yaitu meliputi Kebutuhan keberadaan (Existence Needs), mencakup seluruh bentuk hasrat material dan fisiologis dengan segala variasinya seperti makan, gaji, tunjangan dan kondisi kerja, Kebutuhan relasi (Relatedness Needs) mencakup kebutuhan untuk berhubungan dengan orang lain, apakah dengan keluarga, atasan, bawahan dan kawan- kawan, dan Kebutuhan pertumbuhan (Growth Needs) mencakup kebutuhan yang mendorong seseorang untuk memiliki pengaruh yang kreatif atau produktif terhadap diri sendiri atau lingkungan seperti penghargaan, pengembangan dan kemampuan karyawan sendiri.

Pengaruh motivasi kerja terhadap kepuasan kerja dapat dirujuk dari pendapat Luthans (2005:270) yang berpendapat bahwa salah satu cara untuk menstimulasi karyawan adalah dengan memanfaatkan motivasi secara efektif, yang pada akhirnya akan membuat karyawan merasa lebih puas (more satisfied) dan lebih berkomitmen (more commited) terhadap pekerjaannya. Hasil penelitian Eskildsen et al. (2003) membuktikan bahwa motivasi kerja berpengaruh langsung terhadap kepuasan kerja karyawan. Disebutkan kepuasan kerja karyawan ini jika berdasarkan jenis kelamin adalah sama perlakuannya. Bahwa karyawan laki-laki dan perempuan adalah sama-sama puasnya terkait 
dengan motivasi kerja. Hasil penelitian Khalid et al. (2011) juga menyebutkan motivasi kerja berpengaruh positif terhadap kepuasan kerja karyawan. Berdasarkan tinjauan teori dan hasil penelitian sebelumnya dirumuskan hipotesis penelitian sebagai berikut:

Hipotesis 4 : Motivasi Kerja berpengaruh signifikan terhadap Kepuasan Kerja

\section{Motivasi Kerja dan Kinerja Karyawan}

Menurut Mathis dan Jackson (2006:89) motivasi berasal dari kata "motive". Motivasi merupakan hasrat di dalam seseorang yang menyebabkan orang tersebut melakukan tindakan. Pengaruh motivasi kerja terhadap kinerja karyawan dapat ditunjukkan dalam penelitian Luthans (2006:297) yang melakukan penelitian tentang Managing Russian Factory Workers; The Impact of U.S-Based Behavioral and Participative Techniques. Temuan penelitian menunjukkan bahwa motivasi ekstrinsik di Amerika Serikat memiliki dampak positif pada kinerja karyawan Rusia.

Hasil penelitian Susan et al. (2012) membuktikan bahwa motivasi kerja berpengaruh signifikan terhadap kinerja karyawan, artinya dalam penelitian tersebut adalah semakin diterapkan sebuah strategi dalam perumusan motivasi hal ini akan berdampak pada peningkatan kinerja. Hasil penelitian ini mendukung hasil penelitian Purwati (2011) yang menyimpulkan bahwa motivasi kerja (dalam hal ini adalah kebutuhan akan prestasi dan kebutuhan akan kekuasaan) berpengaruh terhadap kinerja karyawan. Berdasarkan tinjauan teori dan hasil penelitian sebelumnya dirumuskan hipotesis penelitian sebagai berikut: Hipotesis 5 : Motivasi Kerja berpengaruh signifikan terhadap Kinerja Karyawan.

\section{Kepuasan Kerja dan Kinerja Karyawan}

Robbins (2008:107) menyebutkan kepuasan kerja (job satisfaction) dapat didefinisikan sebagai suatu perasaan positif tentang pekerjaan seseorang yang merupakan hasil dari sebuah evaluasi karakteristiknya. Gibson (2006), menyatakan bahwa kepuasan kerja terdiri dari beberapa indikator, antara lain Pembayaran, Pekerjaan; Kesempatan memperoleh promosi.,Penyelia, dan Rekan kerja.

Kinerja adalah hasil atau tingkat keberhasilan seseorang secara menyeluruh sebelum periode tertentu di dalam melaksanakan tugas dibandingkan dengan berbagai kemungkinan, seperti standar hasil kerja, target atau sasaran yang telah ditentukan terlebih dahulu dan telah disepakati bersama (Rivai, 2009). Menurut Dharma (2000:142) mengemukakan bahwa standar dalam penilaian prestasi kerja mencakup: Kuantitas/jumlah yang harus diselesaikan, Kualitas/mutu yang dihasilkan, dan Ketepatan waktu kerja/sesuai tidaknya dengan waktu yang direncanakan.

Konsep pengaruh kepuasan kerja terhadap kinerja karyawan menurut Mathis and Jackson (2006:121), disebutkan bahwa kepuasan kerja adalah keadaan emosional yang positif yang merupakan hasil evaluasi dari pengalaman kerja. Ketidakpuasan kerja muncul ketika harapan seseorang tidak terpenuhi. Hasil penelitian dari Crossman dan Abou-Zaki (2008) membuktikan bahwa kepuasan kerja karyawan berpengaruh terhadap kinerja karyawan. Didukung hasil penelitian dari Qureshi et al. (2011) menyimpulkan bahwa kepuasan kerja berpengaruh secara positif terhadap kinerja karyawan, disebutkan bahwa ketika karyawan bekerja dengan motivasi untuk mencapai tujuan atas nama organisasi bukan untuk kepentingan pribadi sendiri, mereka dapat memberikan hasil yang lebih baik bagi organisasi. Beberapa hasil penelitian di atas berbeda dengan hasil penelitian Edwards et al. (2008) yang lebih memperinci hasil penelitiannya diantaranya adalah ada hubungan yang tidak signifikan antara kepuasan dengan gaji terhadap kinerja tugas, ada hubungan yang signifikan tetapi negatif antara kepuasan dengan kesempatan untuk promosi terhadap kinerja tugas, ada hubungan yang tidak signifikan antara kepuasan dengan rekan kerja terhadap kinerja kontekstual, dan ada hubungan negatif yang signifikan antara kepuasan dengan rekan kerja terhadap kinerja tugas. Sehingga pada akhirnya disimpulkan bahwa beberapa indikator kepuasan kerja (pekerjaan dan 
kesempatan promosi) berpengaruh kuat terhadap kinerja tugas. Sedangkan indikator kepuasan kerja (supervisi) berpengaruh kuat terhadap kinerja kontekstual. Berdasarkan tinjauan teori dan hasil penelitian sebelumnya dirumuskan hipotesis penelitian sebagai berikut:

Hipotesis 6 : Kepuasan Kerja berpengaruh signifikan terhadap Kinerja Karyawan.

\section{Kerangka Konseptual Model Konseptual}

Berdasarkan latar

belakang, rumusan masalah, tujuan penelitian,

uraian teoritis, dan hasil penelitian terdahulu dalam meneliti pengaruh Kompensasi terhadap Motivasi Kerja, Kepuasan Kerja, dan Kinerja Karyawan

(Studi pada PT. Otsuka Indonesia Malang), maka model konseptual dapat disajikan dalam Gambar 1.

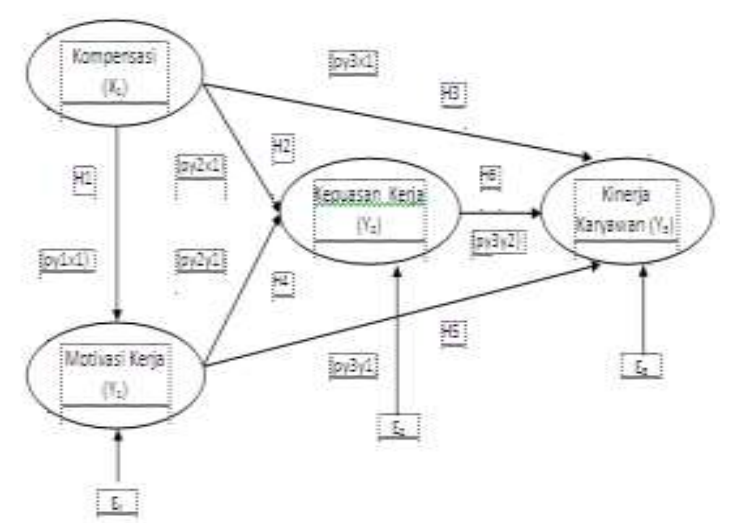

Gambar 1. Model

Konseptual

\section{METODE PENELITIAN}

Jenis penelitian ini termasuk

dalam penelitian eksplanatoris

(explanatory

research) yaitu penelitian yang

berupaya

menjelaskan hubungan kausal antara variabel-variabel melalui pengujian hipotesis (Singarimbun dan Effendi, 1995:5). Lokasi penelitian ini dilaksanakan di PT. Otsuka Indonesia yang berada di Jalan Sumberwaras No 25 Lawang, Malang. Penelitian dilakukan di PT. Otsuka Indonesia atas dasar keberhasilan dan kemampuan PT. Otsuka Indonesia yang tetap konsisten dalam persaingan di pasar produsen medikal klinis. PT. Otsuka Indonesia juga merupakan salah satu perusahaan pelopor produsen produk-produk farmasi di Indonesia, tentunya menarik untuk diteliti terkait kebijakan kompensasinya untuk para karyawannya.

Populasi dalam penelitian ini adalah 451 orang yang merupakan karyawan tetap pada PT. Otsuka Indonesia dan terbagi dalam sepuluh departemen. Sedangkan penetuan sampel dalam penelitian ini menggunakan rumus Slovin sehingga diperoleh jumlah sampel 82 responden. Dari 82 responden dibagi lagi berdasarkan departemen kerjanya menggunalan stratified sampling method sehingga menjadi terbagi dalam Sembilan departemen kerja. Hasil uji validitas dalam penelitian ini didapati bahwa semua butir pernyataan yang digunakan valid, ditunjukkan nilai $\mathrm{r}_{\text {hitung }}>\mathrm{r}_{\text {tabel }}$ dengan nilai signifikansi masing- masing item pernyataan $0,000-0,004$ $<0,05$ sehingga instrumen dalam penelitian ini dapat digunakan sebagai alat pengumpul data yang baik. Dari hasil uji reliabilitas diketahui bahwa nilai reliabilitas yang dicapai pada masing-masing variabel semuanya lebih besar dari 0,6. Dengan demikian instrumen yang digunakan dalam penelitian ini dapat dikatakan reliabel dan handal sebagai alat ukur. Metode pengumpulan data dalam penelitian ini adalah dengan menyebarkan kuesioner dan juga wawancara. 
HASIL DAN PEMBAHASAN

Hasil Analisis Jalur

Gambar 2 Hasil Analisis Jalur

\begin{tabular}{|c|c|c|c|c|c|}
\hline n & Vinistabetor & Tribe Tenis: & beth & 6i, & Kerang \\
\hline & Kometessiol & 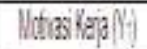 & [W] & $0,4]$ & Sylfikal \\
\hline 2 & Kimeressille & 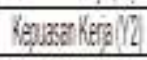 & 1678 & 0002 & Syinifan \\
\hline 3 & Kumcersiol. & 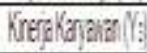 & 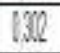 & OMA & Sighifial \\
\hline I & 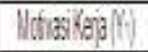 & Kencusa Kas (V: & 1804 & QMV & Sygital \\
\hline 5 & 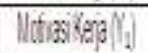 & Krefakanalg) I: & 1200 & 0.27 & Signtal \\
\hline 6 & Fasasankenally & Krerakanalar (Y: & $102^{2}$ & 000 & 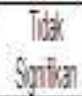 \\
\hline
\end{tabular}

\section{Pengujian Hipotesis}

H2

Hipotesis $\mathrm{H} 2$ menyatakan bahwa terdapat pengaruh langsung yang signifikan dari kompensasi terhadap kepuasan kerja, dengan koefisien jalur

pada hubungan ini sebesar 0,673 dengan signifikansi (sig, $\mathrm{t}=0,000)$, sehingga dapat disimpulkan bahwa data penelitian mendukung hipotesis $\mathrm{H} 2$, pemberian kompensasi yang lebih baik akan meningkatkan kepuasan kerja karyawan. Temuan penelitian ini mendukung penelitian terdahulu yang dilakukan oleh Supatmi (2013) membuktikan bahwa kompensasi berpengaruh secara signifikan terhadap kepuasan kerja pada karyawan BPR Nusamba Wlingi. Demikian hasil penelitian ini juga mendukung hasil penelitian Widodo (2010) yang meneliti para karyawan di kantor pelayanan pajak di Salatiga, dan memberikan suatu kesimpulan kompensasi secara positif dan signifikan berpengaruh terhadap kepuasan kerja.

\section{Pengujian Hipotesis \\ H3}

Hipotesis H3 menyatakan bahwa
terdapat pengaruh langsung yang
signifikan dari kompensasi terhadap
kinerja karyawan, dengan koefisien jalur
pada hubungan ini sebesar 0,302 dengan
signifikansi (sig, t = 0,034), sehingga
dapat disimpulkan bahwa data penelitian
mendukung hipotesis H3, pemberian
kompensasi yang lebih baik akan
meningkatkan kinerja karyawan. Temuan
penelitian ini mendukung penelitian

terdahulu yang dilakukan oleh Prasetya dan Kato (2011) yang meneliti karyawan PT. Telkom Wilayah Malang membuktikan bahwa kompensasi baik finansial dan non finansial mempunyai pengaruh yang signifikan terhadap kinerja karyawan. Demikian hasil penelitian ini juga mendukung hasil penelitian Ulfa (2013) yang meneliti karyawan AUTO 2000

Sutoyo Malang dimana disimpulkan kompensasi finansial dan kompensasi non finansial memiliki pengaruh langsung dan kuat terhadap kinerja karyawan. Hasil penelitian Supatmi (2013) terhadap karyawan BPR Nusamba Wlingi dan hasil penelitian Pramono (2012) terhadap karyawan PT. Adi Mitra Pratama Semarang sama-sama menyebutkan kompensasi berpengaruh signifikan terhadap kinerja karyawan. Hasil penelitian Pratiwi (2013) yang meneliti karyawan PT. Pos Indonesia (Persero) Kantor Cabang Bangkalan juga menyebutkan kompensasi finansial langsung, kompensai finansial tidak langsung, dan kompensasi non finansial teruji berpengaruh signifikan terhadap kinerja karyawan. Berdasarkan pemaparan di atas dapat disimpulkan bahwa dengan peningkatan kompensasi yang diberikan oleh perusahaan, maka akan meningkatkan kinerja karyawan. Besarnya kompensasi ini mencerminkan status, pengakuan dan tingkat pemenuhan kebutuhan karyawan. Jika kompensasi yang diterima karyawan semakin besar berarti jabatannya semakin tinggi, statusnya semakin baik, dan pemenuhan kebutuhan yang akan dinikmati semakin banyak pula, dengan demikian kinerja karyawan juga semakin meningkat.

\section{Pengujian Hipotesis $\mathrm{H} 4$}

Hipotesis $\mathrm{H} 4$ menyatakan bahwa

terdapat pengaruh langsung yang signifikan dari motivasi kerja terhadap kepuasan kerja, dengan koefisien jalur pada hubungan ini sebesar 0,184 dengan signifikansi $($ sig, $\mathrm{t}=0,021)$, sehingga dapat disimpulkan bahwa data penelitian mendukung hipotesis $\mathrm{H} 4$, pemberian motivasi kerja yang lebih baik akan meningkatkan kepuasan kerja karyawan. Temuan penelitian ini mendukung penelitian terdahulu yang dilakukan oleh Khalid et al. (2011) yang meneliti sejumlah karyawan pada perusahaan utilitas air baik sektor publik maupun swasta di Malaysia. Diketahui dari hasil penelitian tersebut bahwa motivasi kerja berpengaruh positif dan signifikan terhadap kepuasan kerja karyawan, walaupun ada perbedaan antara karyawan di 
sektor publik dan swasta, dimana karyawan pada sektor publik lebih menekankan hal tersebut, yaitu dampak motivasi kerja terhadap kepuasan kerja.

Demikian hasil penelitian ini juga mendukung hasil penelitian Eskildsen et al. (2003) yang meneliti dampak motivasi kerja terhadap kepuasan kerja pada 85.000 karyawan di kawasan Negara Nordik (Denmark, Swedia, Norwegia, dan Finlandia). Hasil penelitiannya memberikan suatu kesimpulan secara langsung motivasi kerja berpengaruh terhadap kepuasan kerja. Disebutkan karyawan di Negara Denmark lebih puas dibandingkan Negara kawasan Nordik lainnya, juga disebutkan karyawan laki-laki dan perempuan sama-sama puas terhadap pekerjaan mereka. Berdasarkan dua hasil penelitian acuan di atas dapat disimpulkan bahwa motivasi kerja memang sangat diperlukan oleh seorang karyawan untuk dapat mencapai suatu kepuasan kerja yang tinggi meskipun menurut sifatnya kepusan kerja itu sendiri besarannya sangat relatif atau berbeda antara satu orang dengan orang lainnya.

\section{Pengujian Hipotesis H5}

Hipotesis H5 menyatakan bahwa terdapat pengaruh langsung yang signifikan dari motivasi kerja terhadap

kinerja karyawan, dengan koefisien jalur pada hubungan ini sebesar 0,289 dengan signifikansi (sig, $\mathrm{t}=0,007$ ), sehingga dapat disimpulkan bahwa data penelitian mendukung hipotesis $\mathrm{H} 5$, pemberian motivasi kerja yang lebih baik akan meningkatkan kinerja karyawan secara langsung. Temuan penelitian ini mendukung penelitian terdahulu yang dilakukan oleh Susan et al. (2012) yang meneliti motivasi kerja polisi regular di Nairobi, Kenya. Hasil penelitiannya membuktikan motivasi polisi positif mempengaruhi kinerja mereka. 25,8\% dari perubahan yang sesuai dalam kinerja dapat dijelaskan atau diprediksi oleh perubahan motivasi dengan konstan. Strategi motivasi berhasil diterapkan sesuai harapan, dan mengakibatkan kinerja tinggi yang dalam jangka panjang berdampak pada situasi keamanan secara keseluruhan.

Demikian hasil penelitian ini juga mendukung hasil penelitian Ulfa (2013) memberikan suatu kesimpulan bahwa motivasi kerja memiliki pengaruh secara langsung dan hubungan yang sangat kuat terhadap kinerja karyawan AUTO 2000 Sutoyo di kota Malang. Hasil penelitian Pramono (2012) memberikan suatu kesimpulan motivasi kerja berpengaruh terhadap kinerja karyawan PT. Adi Mitra Pratama Semarang, serta didukung hasil penelitian Purwati (2011) yang meneliti karyawan PT. Anindya Mitra Internasional di Yogyakarta, memberikan suatu kesimpulan secara parsial, dimana motivasi kerja dibagi menjadi kebutuhan akan prestasi, kebutuhan akan kekuasaan, dan kebutuhan akan afiliasi. Kebutuhan akan prestasi dan kebutuhan akan kekuasaan berpengaruh signifikan terhadap kinerja karyawan, sedangkan kebutuhan akan afiliasi berpengaruh tidak signifikan terhadap kinerja karyawan PT. Anindya Mitra Internasional Yogyakarta. Berdasarkan empat hasil penelitian acuan di atas dapat disimpulkan bahwa semakin tinggi motivasi kerja yang dimiliki seorang karyawan maka akan mendorong untuk menghasilkan kinerja karyawan yang baik atau tinggi.

\section{Pengujian Hipotesis H6}

Hipotesis $\mathrm{H} 6$ menyatakan bahwa terdapat pengaruh langsung namun tidak signifikan dari kepuasan kerja terhadap kinerja karyawan, dengan koefisien jalur pada hubungan ini sebesar 0,063 dengan signifikansi (sig, $\mathrm{t}=$ 0,663), sehingga dapat disimpulkan bahwa data penelitian tidak mendukung hipotesis $\mathrm{H} 6$, karena nilai sig. $\mathrm{t}$ melebihi 0,05 . Jadi kepuasan kerja

karyawan pada PT. Otsuka Indonesia tidak meningkatkan atau berdampak besar terhadap kinerja karyawan.

Ditemukannya pengaruh yang tidak signifikan ini dapat diindikasikan dari beberapa indikator kepuasan kerja yang nilainya rendah, yaitu perasaan senang terhadap pembayaran (Y2.1) diperoleh total rata-rata jawaban responden sebesar 3,80 dan perasaan senang terhadap pekerjaan (Y2.2) diperoleh total rata-rata jawaban responden sebesar 3,77. Perasaan senang terhadap pembayaran terdiri dari item-item perasaan senang menerima gaji, perasaan senang menerima insentif/bonus, dan perasaan senang menerima tunjangan. Artinya karyawan PT. Otsuka Indonesia yang sudah puas dengan gaji yang didapatkannya dalam waktu yang lama 
hal tersebut akan dirasa menjadi hal yang biasa. Sehingga rawan akan menurunnya kinerja, karena dengan bekerja santai ataupun bekerja keras gajinya akan tetap didapatkan dengan jumlah yang sama. Perasaan senang terhadap pekerjaan terdiri dari item-item kesesuaian kemampuan dengan tanggung jawab, pekerjaan yang menarik, dan pekerjaan bagaikan hobi. Karyawan PT. Otsuka Indonesia merasa tanggung jawab pekerjaan

yang dilakukan selama ini belum sepenuhnya sesuai dengan

kemampuannya artinya prinsip "the right man on the right place" belum dirasakan oleh karyawan PT. Otsuka Indonesia. Pekerjaan yang menarik dan pekerjaan bagaikan hobi juga belum dirasakan karyawan PT. Otsuka Indonesia karena mengacu belum sesuainya kemampuan karyawan dengan tanggung jawab yang harus dirasakannya.

Temuan penelitian ini tidak mendukung hasil penelitian terdahulu, diantaranya hasil penelitian Qureshi et al. (2011) yang menyebutkan bahwa kepuasan kerja berpengaruh kuat dan signifikan terhadap kinerja karyawan yang

bekerja di sektor-sektor yang berbeda dari organisasi di Rawalpindi di Pakistan. Hasil penelitian Crossman dan Abou-Zaki (2003) juga menyebutkan secara keseluruhan kepuasan kerja berpengaruh terhadap kinerja karyawan bank umum di Lebanon, walaupun juga diperinci lebih dalam disebutkan karyawan perempuan lebih puas untuk masalah gaji daripada karyawan laki-laki. Karyawan laki-laki lebih puas dalam hal pengawasan daripada karyawan perempuan. Hasil penelitian ini juga bertentangan dengan hasil penelitian Supatmi (2013) yang menyimpulkan kepuasan kerja berpengaruh signifikan terhadap kinerja karyawan BPR Nusamba Wlingi. Hasil penelitian Soegihartono (2012) yang meneliti karyawan tetap PT. Alam Kayu Sakti Semarang juga menambahkan bahwa kepuasan kerja berpengaruh terhadap kinerja karyawan dan merupakan faktor dominan yang mempengaruhinya.

Namun hasil penelitian ini mendukung hasil penelitian Edwards et al. (2008) yang meneliti karyawan perusahaan manufaktur di Texas Selatan,
Amerika Serikat. Disebutkan bahwa ada hubungan yang tidak signifikan antara kepuasan dengan gaji terhadap kinerja tugas. Selain itu, hubungan antara kepuasan dengan kesempatan untuk promosi terhadap kinerja tugas yang signifikan tetapi negatif. Disebutkan juga ada hubungan yang tidak signifikan antara kepuasan dengan rekan kerja terhadap kinerja kontekstual. Artinya, supervisor atau atasan mungkin tidak memiliki kesempatan untuk mengamati interaksi antara rekan kerja. Selain itu, perilaku kinerja kontekstual mungkin lebih penting bagi organisasi ketika mereka diarahkan supervisor daripada rekan kerja. Serta ada hubungan negatif yang signifikan antara kepuasan dengan rekan kerja terhadap kinerja tugas dimana hubungan ini mungkin bahwa karyawan yang puas dengan rekan kerja mereka dapat menghabiskan lebih banyak waktu terlibat dalam kegiatan non-tugas dengan sesama rekan kerja (misalnya sedang bebas tugas dan mengobrol, makan siang yang panjang), sehingga kinerja tugas menjadi lebih rendah.

\section{Keterbatasan Penelitian}

masih ada keterbatasan penelitian. Keterbatasan penelitian

tersebut menyangkut penyebaran

kuesioner hanya bisa dititipkan pada masingmasing Kepala Departemen juga membuat datadata penelitian rawan akan bias dan kerancuan. Hal ini dikarenakan ketatnya aturan di perusahaan apabila seorang peneliti yang mengkoordinir dan memberi petunjuk sendiri tentang pengisian kuesioner, dikhawatirkan hal tersebut akan mengganggu proses bekerja para karyawan, terutama pada karyawan departemen produksi yang hanya akan ada waktu senggang menjelang selesainya shift atau bagian jam kerja mereka berakhir dan berganti shift berikutnya.

\section{KESIMPULAN DAN SARAN \\ Kesimpulan}

Berdasarkan hasil penelitian, hasil analisis data, dan pembahasan hasil penelitian serta pengujian hipotesis yang dilakukan, maka dapat ditarik kesimpulanpenelitian ini sebagai berikut:

a. Terdapat pengaruh yang signifikan dari kompensasi terhadap motivasi kerja karyawan PT. Otsuka Indonesia. Dapat disimpulkan bahwa tinggi atau rendahnya tingkat kompensasi akan berdampak terhadap motivasi kerja. Semakin tinggi kompensasi akan mendorong motivasi kerja karyawan semakin 
baik, sedangkan rendahnya kompensasi turut menurunkan motivasi kerja karyawan.

b. Terdapat pengaruh yang signifikan dari kompensasi terhadap kepuasankerja karyawan PT. Otsuka Indonesia.

Dapat disimpulkan bahwa tingkat kompensasi yang lebih baik terhadap karyawan akan dapat meningkatkan kepuasan kerja karyawan. Dan sebaliknya,semakin menurunnya kompensasi pada karyawan turut menurunkan kepuasan kerja karyawan.

c. Terdapat pengaruh yang signifikan dari kompensasi terhadap kinerja karyawan PT. Otsuka Indonesia. Hal ini berarti pemberian kompensasi yang lebih baik akan berbanding lurus dampaknya dengan meningkatnya kinerja karyawan.

d. Terdapat pengaruh yang signifikan dari motivasi kerja terhadap kepuasan kerja karyawan PT. Otsuka

Indonesia. Hal ini menunjukkan bahwa semakin tinggi motivasi kerja yang dirasakan karyawan maka akan semakin tinggi pula kepuasan kerja karyawan.

e. Terdapat pengaruh yang signifikan dari motivasi kerja terhadap kinerja karyawan PT. Otsuka Indonesia. Dapat disimpulkan bahwa meningkatnya motivasi kerja karyawan juga mendukung peningkatan kinerja karyawan.

f. Ditemukan pengaruh yang tidak signifikan dari kepuasan kerja terhadap kinerja karyawan PT. Otsuka Indonesia. Hal ini bisa diindikasikan dari indikator kepuasan kerja yaitu perasaan senang terhadap pembayaran dan perasaan senang terhadap pekerjaan. Artinya karyawan PT. Otsuka Indonesia yang sudah puas dengan gaji yang didapatkannya dalam waktu yang lama hal tersebut akan dirasa menjadi hal yang biasa. Sehingga rawan akan menurunnya kinerja, karena dengan bekerja santai ataupun bekerja keras gajinya akan tetap didapatkan dengan jumlah yang sama. Karyawan PT. Otsuka Indonesia juga merasa tanggung jawab pekerjaan yang dilakukan selama ini belum sepenuhnya sesuaidengan kemampuannya artinya prinsip "the right man on the right place" belum dirasakan oleh karyawan PT. Otsuka Indonesia.
Pekerjaan yang menarik dan pekerjaan bagaikan hobi juga belum dirasakan karyawan PT. Otsuka Indonesia karena mengacu belum sesuainya kemampuankaryawan dengan tanggung jawab yang harus dirasakannya.

\section{Saran}

Dari hasil penelitian, diajukan

beberapa saran yang bisa digunakan sebagai bahan pertimbangan bagi peneliti lain dalam bidang pengembangan sumber

daya manusia yang akan melakukan penelitian lanjutan dan kebijakan praktis bagi PT. Otsuka Indonesia, adalah sebagai berikut:

\section{Penelitian Selanjutnya}

a. Mengembangkan variabel-variabel bebas lain yang dapat mempengaruhi kinerja karyawan. Misalnya kepemimpinan, komitmen organisasi, budaya organisasi, ataupun pelatihan. Hal ini sejalan dengan beberapa referensi dari penelitian-penelitian terdaulu yang digunakan sebagai acuan dan perbandingan dalam penelitian ini.

b. Penambahan jumlah sampel akan memberikan hasil yang berbeda pada hasil penelitian. Karena dengan sampel yang lebih banyak akan terdapat banyak kemungkinan temuan penelitian terbaru yang berguna bagi acuan penelitian-penelitian di masa yang akan datang.

\section{Praktis}

PT. Otsuka Indonesia lebih memfokuskan perhatian yang terkait dengan kompensasi baik itu kompensasi finansial dan kompensasi non finansial serta motivasi kerja (kebutuhan keberadaan, kebutuhan relasi, dan kebutuhan pertumbuhan), hal ini agar berbanding lurus peningkatannya dengan kinerja karyawan. Kedua hal tersebut harus ditingkatkan lagi nilai dan penghargaannya oleh PT. Otsuka Indonesia kepada karyawaannya karena diketahui berpengaruh signifikan terhadap kinerja karyawan. Kepuasan kerja tidak perlu lagi diperhatikan karena diketahui pengaruhnya tidak signifikan terhadap kinerja karyawan. hal-hal yang terkait kepuasan kerja karyawan.

\section{DAFTAR PUSTAKA}

Arikunto, Suharsimi. 2006. Prosedur Penelitian Suatu Pendekatan Praktek. Rineka Cipta. Jakarta.

As'ad, Mohammad. 2000. Psikologi 
Industri. Edisi Keempat. Penerbit Liberty. Yogyakarta.

2004. Psikologi

Industri. Edisi Keempat. Penerbit Liberty.Yogyakarta.

Bernardin, H. John and Joyce E.A.

Russel. 1993. Human Resource Management. Mc Graw Hill, Inc. Singapore.

Crossman, Alf and Bassem Abou-Zaki. 2003. "Job Satisfaction And Employee Performance Of Lebanese Banking Staff". Journal of Managerial Psychology, Vol. 18 No. 4, pp. 368376.

Daft, Richard L. 2006. Management, Edisi 6. Salemba Empat. Jakarta.

Davis, Keith. 1991. Human Behaviour At Work: Organizational Behaviour, Sixth Edition, Mc Grawhill,Inc.

Dessler, Gary. 1993. Manajemen Personalia:Edisi Ketiga. Penerbit Erlangga. Jakarta.

2000. Manajemen Prestasi Kerja Edisi Kedua, CV. Rajawali. Jakarta.

Edwards, Bryan D., Suzanne T.Bell, Winferd Arthur Jr., and Arlette D. Decuir. 2008. "Relationships between Facets of Job Satisfaction and Task and Contextual Performance". Applied Psychology: An International Review Vol. 57 (3), pp. 441-465.

Eskildsen, Jacob K., Kai Kristensen, and Anders H. Westlund. 2003. "Work Motivation And Job Satisfaction In The Nordic Countries". Emerald Group Publishing Limited Vol. 26 No.

2, pp. 122136.

Gibson, James L.. 2006.

2006.

Organisasi: Perilaku, Struktur Dan Proses, Edisi 8. Alih bahasa oleh Nunuk Adriani, Binarupa Aksara. Jakarta.

Gujarati, Damodar. 1997. Ekonometrika

Dasar. Erlangga, Jakarta. Hasibuan, Malayu S.P., 2002. Manajemen

Sumber Daya Manusia, Cetakan Kelima, Edisi Revisi. Bumi Aksara. Jakarta.

Khalid, Khalizani., Hanisah Mat Salim, and

Siew-Phaik Loke. 2011. "The Impact of Rewards and Motivation on Job

Satisfaction in Water Utility Industry". International Conference on Financial Management and Economics IPEDR Vol.11.

Koontz., Harold Cryl O'Donnel, dan Heinz Weihnch. 1996. Management, Edisi Kedelapan, Alih Bahasa: $\mathrm{H}$. Gunawan. Erlangga, Jakarta.

Kuncoro, Mudrajad. 2003. Metode Riset untuk Bisnis \& Ekonomi. Erlangga. Jakarta.

Luthans, Fred. 2002. Organizational Behaviour. $9^{\text {th }}$ Edition. Mc Graw- Hill. 2005. Perilaku Organisasi.

Edisi Sepuluh. Alih bahasa: Vivin Andhika Yuwono, Shekar Purwanti, Th. Arie Prabawati dan Winong Rosari. Penerbit Andi. Yogyakarta.

2006. Organizational

Behaviour, $10^{\text {th }}$ edition, Alih Bahasa: Vivin Andhika Yuwono, Shekar

Purwanti, Th. Arie Prabawati dan Winong Yogyakarta. Rosari., Penerbit Andi,

Mangkunegara, Anwar Prabu. 2005.

Evaluasi Kinerja SDM, Cetakan

Kedua. PT Refika Aditama. Bandung. 2009.

Manajemen Sumber Daya Manusia

Perusahaan. PT. Indeks. Jakarta. Mangkuprawira, Sjafri. 2003. Manajemen

Mutu Sumber Daya Manusia

Strategik. Ghalia Indonesia. Bogor.

Mutu Sumber Daya Manusia

Strategik. Ghalia Indonesia. Bogor.

Martoyo, Susilo. 2000. Manajemen 
Sumber Daya Manusia, Edisi 4. BPFE. Yogyakarta.

Mathis, Robert L. and John H Jackson.

2006. Human Resource Management (Manajemen Sumber Daya Manusia), Edisi 10, Alih bahasa: Diana Angelica. Salemba Empat.Jakarta.

2009. Human Resource Management

(Manajemen Sumber Daya Manusia), Edisi 10, Alih Bahasa: Diana Angelica. Salemba Empat. Jakarta.

Mondy, R. Wayne.2008. Manajemen Sumber Daya Manusia. Penerbit Erlangga. Jakarta. Notoatmodjo, Soekidjo. 2003.

Pengembangan Sumber Daya

Manusia. PT. Rineka Cipta. Jakarta. Pramono, Agus. 2012. "Pengaruh

Kompensasi, Motivasi, Lingkungan Kerja Dan Kepemimpinan Terhadap Kinerja Karyawan".

Prasetya, Arik and Masanori Kato. 2011.

"The Effect Of Financial And Non

Financial Compensation To The

Employee Performance".

International Research Symposium In

Service Management Yogyakarta.

Pratiwi, Agustin. 2013. "Pengaruh

Kompensasi Terhadap Kinerja

Karyawan". Jurnal Pengaruh Kompensasi Terhadap Kinerja Karyawan 2013.

Purwati, Sri. 2012. "Pengaruh Motivasi

Kerja Karyawan Terhadap Kinerja

Karyaw

an".

Qureshi, Javeria Ashfaq., Khansa Hayat, Mehwish Ali, and Nosheen Sarwat

2011. "Impact of Job Satisfaction and Organizational Commitment on Employee Performance, Evidence from Pakistan". Interdisciplinary Journal Of Contemporary Research In Business Institute Vol 3, No 4.
Riduwan, dan Engkos Achmad Kuncoro.

2008. Cara Menggunakan dan

Memaknai Analisis Jalur (Path

Analysis). Alfabeta. Bandung

2011. Cara Menggunakan dan Memaknai Analisis Jalur (Path Analysis). Cetakan Ketiga. Penerbit Alfabeta. Bandung.

2009. Manajemen Sumber Daya Manusia Untuk Perusahaan Dari

Teori ke Praktik. PT Rajawali Pers. Jakarta.

2008. Organizational

Behaviour. Penerjemah : Diana

Angelica. Salemba Empat. Jakarta.

Schermerhom, J.R., 2000. Manajemen, Buku 2, Penerjemah Pernama

Putranta, Surya Dharma Ginting, MF

Sheelyana Junaedi, Th. Diah

Widiastuti Edisi I. Penerbit Andi.

Yogyakarta.

Sekaran, Uma. 2006. Research Methods for Business, Buku 2. Edisi 4. Salemba Empat. Jakarta.

Simamora, Henry. 2006. Manajemen Sumber Daya Manusia, Edisi III, Cetakan Yogyakarta. Kedua. STIE YKPN.

Singarimbun dan Effendi . 1995. Metode Venelitian Survei. LP3ES. Jakarta. Soegihartono, A., 2012. "Pengaruh

Kepemimpinan dan Kepuasan Kerja Terhadap Kinerja dengan Mediasi Komitmen". Jurnal Mitra Ekonomi dan Manajemen Bisnis, Vol.3, No. 1, pp

123-140.

Solimun, 2008. Memahami Model Kuantitatif Mutakhir :Struktural Equation Modelling \& Partial Least Square. Program Studi Statistika FMIPA. Universitas Brawijaya Malang.

Stringer, Carolyn., Jeni Didham, and Paul Theivananthampillai. 2011.

"Motivation, Pay Satisfaction, And Job Satisfaction Of Front-Line Employees". Qualitative Research in Accounting \& Management. Vol. 8 No.2. 
Sugiyono. 2008. Metode Penelitian Bisnis.

Cetakan Keduabelas. Penerbit

Alfabeta,

Bandung.

. 2010. Metode penelitian

Kuantitatif Kualitatif dan

$R \& D$, Penerbit Alfabeta. Bandung.

Supatmi, Mamik Eko. 2013. "Pengaruh

Pelatihan, Kompensasi Terhadap

Kepuasan Kerja Karyawan

Dan Kinerja Karyawan" . J u $r$ n a l

Profit Vo lume $7 \mathrm{No} .1$.

Supranto, J. 2004. Analisis Multivariat: Arti dan Interpretasi. Edisi Pertama, Jakarta: Penerbit Rineka Cipta.

Susan, Were M., R.W. Gakure, E.K.

Kiraithe, and A.G. Waititu. 2012. "Influence of Motivation on Performance in the Public Security Sector with a Focus to the Police Force in Nairobi, Kenya". International Journal of Business and Social Science Vol. 3 No. 23.

Susetyo, Budi. 2010. Statistik untuk Analisis Data

Penelitian. Bandung:Refika Aditama.

Sutrisno, Edy. 2009. Manajemen Sumber

Daya Manusia. Kencana. Jakarta. Trivella, Panagiotis., Nikos Kakkos, and

Panagiotis Reklitis. 2010. "Investigating The Impact Of

Motivation On Loyalty And Performance Intentions In The Greek Banking Sector". 7th International Conference on Enterprise Systems, Accounting and Logistic.

Ulfa, Maria. 2013. "Pengaruh Kompensasi Terhadap Motivasi Kerja dan Kinerja Karyawan".

Wibowo. 2009. Manajemen Kinerja. Edisi

Kedua. Penerbit Rajawali Press. Jakarta.

2011. Manajemen Kinerja. Edisi

Ketiga. Penerbit Rajawali Press.

Jakarta.

Widodo ， Parwoto. 2010. "Pengaruh
Lingkungan Kerja Pada Hubungan Antara Kompensasi Dan Kepemimpinan Terhadap Kepuasan Kerja Studi Pada Kantor Pelayanan Pajak Salatiga".

Wirawan. 2009 . Evaluasi Kinerja Sumber Daya Manusia Teori, Aplikasi, dan Penelitian. PT. Salemba Empat. Jakarta. 